\title{
Herbaceous layer development during spring does not deplete soil nitrogen in the Portuguese montado
}

\author{
D.O. Otieno ${ }^{\mathrm{a}, *}$, H. Mirzaei $^{\mathrm{b}}$, M.Z. Hussain ${ }^{\mathrm{e}}$, Y.L. Li ${ }^{\mathrm{c}}$, M.W.T. Schmidt ${ }^{\mathrm{a}, 1}$, M. Wartinger ${ }^{\mathrm{a}, 1}$, E. Jung ${ }^{\mathrm{a}, 1}$, \\ N. Ribeiro ${ }^{\mathrm{d}}$, J.S. Pereira ${ }^{\mathrm{e}}$, J. Tenhunen ${ }^{\mathrm{a}, 1}$ \\ a Department of Plant Ecology, University of Bayreuth, P.O. Box 95440, Bayreuth, Germany \\ ${ }^{\mathrm{b}}$ Razi University, Kermanshah, Iran \\ ${ }^{\mathrm{c}}$ South China Botanical Garden, Chinese Academy of Sciences, Guangzhou 510650, China \\ d Departamento de Fitotecnia, Universidade de Évora, Pólo da Mitra, Apartado 94, 7002-554 Évora, Portugal \\ e Instituto Superior de Agronomia, Tapada da Ajuda, 1394-017 Lisbon, Portugal
}

\section{A R T I C L E I N F O}

\section{Article history:}

Received 8 March 2010

Received in revised form 13 October 2010

Accepted 27 October 2010

Available online 26 November 2010

\section{Keywords:}

Biomass development of the herbaceous

vegetation

Mediterranean ecosystems

Portuguese montado

Pasture

Plant and soil nitrogen pools

Root distribution and nutrient uptake

Soil moisture

\begin{abstract}
A B S T R A C T
Nitrogen $(\mathrm{N})$ content in the soil and in the herbaceous biomass were monitored during spring of 2004-2006 to determine how the herbaceous layer development influences soil $\mathrm{N}$ availability in the montado ecosystem of southern Portugal. Highest $\left(246.6 \pm 52.7 \mathrm{~g} \mathrm{~m}^{-2}\right)$ and lowest $\left(123.2 \pm 89.5 \mathrm{~g} \mathrm{~m}^{-2}\right)$ peak biomass occurred in 2006 and 2005 respectively. Total soil $\mathrm{N}$ within the top $20 \mathrm{~cm}$ soil profile ranged

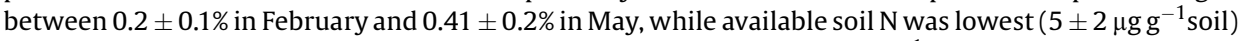
in February but increased three-to-five fold in March and was $>17.5 \mu \mathrm{g} \mathrm{g}^{-1}$ soil at senescence in May. Significant $(p<0.001)$ increase in total $N$ in the aboveground pool occurred between February and May. There was however, no decay in soil $\mathrm{N}$ content. Instead, the herbaceous vegetation enhanced soil $\mathrm{N}$ input and $\mathrm{N}$ retention in the ecosystem. Most of the herbaceous plants were annuals with large reserves of organic $\mathrm{N}$ at senescence, which returned to the soil as detritus. The herbaceous vegetation is a critical component of the montado that contributes to $\mathrm{N}$ recharge and cycling within the ecosystem.
\end{abstract}

(C) 2010 Elsevier Ltd. All rights reserved.

\section{Introduction}

Montado, a two-layered vegetation structure covers approximately 2-2.5 million ha in the Iberian Peninsula and is dominated by a continuous layer of herbaceous biomass and widely distributed trees (Joffre and Lacaze, 1993; Joffre et al., 1988, 1999). The tree-component is comprised of the evergreen oak species, mainly Quercus suber and Quercus rotundifolia (Bugalho et al., 2009). The herbaceous layer has a rich biological diversity and is considered as habitats to be preserved (Moreno et al., 2005a). Due to its extent, the herbaceous layer provides a larger photosynthetic surface compared to the trees and could play a significant role in carbon fixation and ecosystem productivity (Pereira et al., 2007; Aires et al., 2008; Li et al., 2008) as well as influence soil nutrient and water balance (Joffre, 1990; Moreno et al., 2007). Due to the semiarid nature of the montado, the life cycle of the herbaceous plant

\footnotetext{
* Corresponding author. Tel.: +49 92155 2325; fax: +49 921552564.

E-mail address: denotieno@yahoo.com (D.O. Otieno).

1 Tel.: +49 92155 2325; fax: +49 921552564 .
}

community is confined to spring when soil moisture and temperatures favor their growth and development (Otieno et al., 2006; Pereira et al., 2007).

Most studies in the Mediterranean tree-grass mosaic focus on the effects of trees on the herbaceous layer production (Joffre and Rambal, 1988; Joffre, 1990; Jackson et al., 1990; Gallardo, 2003; Moreno et al., 2005a; Moreno, 2008). Limited information however, exists on how the understory vegetation influences soil nutrient availability and hence the overall ecosystem production. The nature of the herbaceous layer development suggests that it may play a role in the availability and distribution of soil resources, with significant implications on ecosystem functioning (Whitehead, 1995) since the soil nutrient and water store is limited (Aires et al., 2008). Studies have shown positive effects of understory clearance on the physiological status (Infante et al., 1999; Moreno and Cubera, 2008) and productivity (Diaz et al., 1997) of the remaining trees. The improved physiological status of the trees could be due to an increase in the available soil volume, and thus water and nutrients for the individual trees (Moreno et al., 2005b). Woodmansee and Duncan (1980), Joffre (1990) and Gallardo et al. (2000) have shown a rapid increase in 
nitrogen $(\mathrm{N})$ in the herbaceous layer biomass between February and April in the Mediterranean regions, while soil extractable nitrogen was at its lowest. This however, is also the period when maximum growth of trees occurs (Otieno et al., 2006). The proliferation of the herbaceous layer in spring results in the accumulation of nitrogen in the aboveground biomass and may lead to a significant reduction in soil $\mathrm{N}$ and its limitation. Although extensive rooting system of trees may allow them to operate outside the boundaries of the herbaceous layer and they could access nutrient resources located in the deep soil layers (Moreno et al., 2007), the strategy is only relevant when the system allows deep soil layers to be systematically recharged.

Mediterranean ecosystems are water controlled and microbial biomass and $\mathrm{N}$ mineralization are regulated by moisture dynamics (Joffre, 1990; Gallardo et al., 2000). In the Mediterranean region of Spain, which resembles the Portuguese montado, major organic matter input into the soil occurs during spring and summer while potential maximum nitrification is reached in spring, with a significant increase in soil extractable nitrogen between February and June (Gallardo et al., 2000). Low mineralization and soil N input in winter is due to low temperatures and anaerobic conditions (Whitehead, 1995), while nitrification is inhibited by dry soil conditions, restricting the amount of available $\mathrm{N}$ (Garwood and Tyson, 1973). Thus nitrogen input in spring should be adequate to support biomass development of the herbaceous layer without depleting the soil $\mathrm{N}$ store during spring and early summer, since the period also coincides with active mineralization and soil $\mathrm{N}$ input. In this study, we examined the dynamics of nitrogen in relation to biomass development of the herbaceous layer community during the active growing period in spring. We attempt to answer the following questions: 1 . How does $\mathrm{N}$ distribution in the soil and plant pools relate to biomass development of the herbaceous layer plant community? 2. Is there a possible limitation of soil $\mathrm{N}$ created by the rapid growth of the herbaceous layer community in spring?

\section{Materials and methods}

\subsection{Study site and plant species}

The experimental site was located in the center of the Alentejo Province, southern Portugal, at Herdade da Mitra $\left(38^{\circ} 32^{\prime} \mathrm{N}\right.$, $88^{\circ} 00^{\prime} \mathrm{W}, 243 \mathrm{~m}$ a.s.l.) near the Mitra campus of the University of Evora. Measurements were carried out during the spring periods of 2004, 2005 and 2006. The climate in Mitra is Mediterranean, with hot and dry summers. Annual precipitation ranges between 350 and $650 \mathrm{~mm}$, occurring between October and April. Between 2004 and 2006 rainfall patterns typical of this Mediterranean region of Portugal (Corte-Real et al., 1998) were experienced, but with significant inter-annual variations. Compared to 2004 and 2006, the hydrological year 2005 was drier, with precipitation amounts below the long-term mean. The hydrological year 2006 was the wettest with rainfall record between October and April amounting to $561 \mathrm{~mm}(2005=314 \mathrm{~mm}$ and $2004=481 \mathrm{~mm})$. The soils were shallow (ca. $30 \mathrm{~cm}$ deep) sandy Cambisols (FAO, 1988) overlying a fractured gneiss rock, with low water retention capacity. Soil characteristics of the top $20 \mathrm{~cm}$ soil profile are shown in Table 1.

The vegetation is typical for the montado and the dominant tree species are $Q$. suber and $Q$. rotundifolia at a density of 40-50 trees ha ${ }^{-1}$, comprising an overstory with ca. $35 \%$ of tree canopy cover. The understory comprises a rich diversity of plant species that can be grouped into 3 functional types of forbs, grasses and legumes. Approximately $70 \%$ of the herbaceous community consisted of annuals, while $30 \%$ were perennials (Supplementary material).

\subsection{Measurements}

\subsubsection{Above- and belowground biomass sampling}

Monthly biomass determinations were conducted during spring of the three years. Active growth of the herbaceous layer was confined to the spring period between March and May, due to low temperatures between November and February and drought that occurs from June to September (Otieno et al., 2006; Pereira et al., 2007). The choice of sampling period was, therefore, based on the active vegetative period (spring) of the herbaceous layer. During January 2004, an area measuring $100 \mathrm{~m}$ by $100 \mathrm{~m}$ was demarcated for our studies. The study area was relatively uniform, with an even topography. The demarcated area was representative of the Mitra region. Grazing by domestic animals was excluded between February and May during the period when we conducted sampling, otherwise the fields were grazed during the rest of the year. This was necessary in order to allow for the quantification of the total $\mathrm{N}$ shifted to the aboveground biomass pool during plant growth.

During each monthly sampling, 15 sampling plots (quadrats) measuring $25 \mathrm{~cm}$ by $25 \mathrm{~cm}$ were randomly established across the study site for aboveground biomass harvesting. Each plot was established at least $10 \mathrm{~m}$ from the nearest tree to avoid the influence of trees and their roots on nutrient and biomass. From each plot, aboveground biomass was cut to the ground level and the harvested biomass separated into forbs, grass and legumes before being oven-dried at $80{ }^{\circ} \mathrm{C}$ for $48 \mathrm{~h}$ and weighed to determine aboveground shoot biomass. The harvested plots were clearly marked and numbered to avoid repeated harvesting in the subsequent months. New plots were established on fresh, undisturbed locations during subsequent months. After cutting the aboveground biomass, soil cores were obtained from the center of each of the plots using an $8 \mathrm{~cm}$-diameter core sampler. The soil cores were separated into layers of $0-3,3-7$ and $7-12 \mathrm{~cm}$ depths. Roots were separated from the soil by washing the soil samples under running tap water in a $0.5 \mathrm{~mm}$ sieve. The roots were oven-dried at $80^{\circ} \mathrm{C}$ for $48 \mathrm{~h}$ and weighed to determine root biomass.

\subsubsection{Soil and plant nitrogen $(N)$ determination}

On the same day as biomass sampling, a second soil core was obtained from the same location, next to the root sampling point, down to $20 \mathrm{~cm}$ soil depth for soil $\mathrm{N}$ analysis using an $8 \mathrm{~cm}$-diameter core sampler. A set of 15 soil samples was obtained from the study site at any monthly sampling period. The fresh soil samples from the respective plots were divided into layers of $0-3,3-7,7-12$ and $12-20 \mathrm{~cm}$ depths. Samples from each layer were then divided into two equal parts. One set of samples was used for the determination of soil nitrogen. The second set, from the 4 respective layers, was used for the determination of soil $\mathrm{pH}$. Soil $\mathrm{pH}$ was determined by filling $20 \mathrm{~g}$ of fresh ground and homogenized soil into plastic bottles with $50 \mathrm{ml}$ of distilled water and shaking for $1 \mathrm{~h}$. A calibrated $\mathrm{pH}$-meter was used for $\mathrm{pH}$ determination.

Available soil nitrogen was extracted by shaking $100 \mathrm{~g}$ of fresh, homogenized soil with $250 \mathrm{ml}$ of $1 \mathrm{M} \mathrm{KCl}$. The extracted solution

Table 1

Physical and chemical soil characteristics of the study site in Mitra.

\begin{tabular}{|c|c|c|c|c|c|c|c|c|}
\hline \multirow[t]{2}{*}{ Depth $(\mathrm{cm})$} & \multirow[t]{2}{*}{ Bulk density $\left(\mathrm{g} \mathrm{cm}^{-3}\right)$} & \multicolumn{3}{|c|}{ Texture } & \multirow[t]{2}{*}{$\mathrm{pH}$} & \multirow[t]{2}{*}{$\% \mathrm{C}$} & \multirow[t]{2}{*}{$\% \mathrm{~N}$} & \multirow[t]{2}{*}{$\mathrm{C}: \mathrm{N}$} \\
\hline & & $\%$ Sand & \%Silt & \%Clay & & & & \\
\hline $0-20 \mathrm{~cm}$ & $1.54 \pm 0.3$ & 70 & 21 & 9 & $6.4 \pm 0.5$ & $1.4 \pm 0.9$ & $0.1 \pm 0.1$ & $11.5 \pm 2$ \\
\hline
\end{tabular}


was filtered and transferred into Szinti-containers (plastic) for the determination of $\mathrm{N}-\mathrm{NH}_{4}^{+}$and $\mathrm{N}-\mathrm{NO}_{3}^{-}$concentrations. $\mathrm{N}-\mathrm{NH}_{4}^{+}$was determined by means of Flow Injection Analysis (FIA) methodology, while $\mathrm{N}-\mathrm{NO}_{3}^{-}$was determined by means of anion exchange-HPLC and UV-detection. Analysis of the available soil nitrogen was conducted for spring 2004 and 2005, while plant nitrogen was analyzed during spring for three consecutive years.

A portion of soil, below- and aboveground plant samples were dried at $80{ }^{\circ} \mathrm{C}$ and homogenized in a ball mill. The homogenized samples were re-dried in a desiccator to eliminate all the water. A portion of the dried samples, 4-5 and 15-100 mg of plant and soil samples respectively, were then analyzed to determine their $\mathrm{N}$ content (\%) by means of elementary analysis (Markert, 1996). Total $\mathrm{N}$ uptake of the aboveground biomass was determined from the total aboveground biomass and expressed as $\mathrm{g} \mathrm{m}^{-2}$. Similarly, total root $\mathrm{N}$ uptake was calculated from the total belowground biomass.

\subsection{Statistical analysis}

Statistical analysis was performed using SPSS (SPSS 15.0 for Windows, SPSS Inc., Chicago, USA). Significance level was set to $P \leq 0.05$. Data on plant biomass, soil and plant nitrogen were compared between soil layers, months and years using two-way ANOVA, with soil layers, months and years as the fixed effects. Similar comparisons were made for $\mathrm{N}$ uptake between plant groups. Normality was confirmed via stored residuals. Where significant differences were found, a post hoc test for pairwise comparison of means was conducted using Tukey-HSD test.

\section{Results}

\subsection{Biomass development}

Rapid increase in the aboveground biomass of the herbaceous layer occurred between February and May, coinciding with the wet period (Figs. 1 and 2). Peak aboveground biomass occurred in May and was $246.6 \pm 52.7 \mathrm{~g} \mathrm{~m}^{-2}$ in 2006, $123.2 \pm 49.2 \mathrm{~g} \mathrm{~m}^{-2}$ in 2005 and $169.26 \pm 89.5$ in 2004. Analysis of variance showed no interaction ( $p=0.11$ ) between year and peak aboveground biomass. Differences between the monthly biomass were however, significant $(p<0.001)$. Most of the aboveground biomass was withered by the end of May. This pattern was observed each year. No significant $(p=0.24)$ differences in root biomass were observed between the years, while variations in root biomass between the months were significant $(p<0.05)$. Peak root biomass occurred in April during the three years (Fig. 3b). We were unable to recognize and separate new roots (current year growth) from old roots of the previous year, and there is likelihood that a fraction of the root biomass indicated might be a carry-over from the previous year(s).

\subsection{Plant nitrogen}

Changes in plant aboveground biomass and plant $\mathrm{N}$ during spring followed the same pattern. There was a 2- to 5-fold increase of $\mathrm{N}$ in the aboveground plant biomass (aboveground biomass pool) between February and May (Fig. 3 upper panel), associated with the period of active biomass development. Highest $\mathrm{N}$ content in the aboveground biomass pool occurred at peak biomass in May while the lowest was observed in February. Highest peak $\mathrm{N}$ uptake recorded in the aboveground biomass pool was $5 \mathrm{~g} \mathrm{~m}^{-2}$ and occurred in 2006, while the lowest was $1.6 \mathrm{~g} \mathrm{~m}^{-2}$ in 2005. Differences in $\mathrm{N}$ in this pool between the years and also between the months were significant. Nitrogen in the belowground biomass pool (root biomass) was concentrated within the top $0-3 \mathrm{~cm}$ soil profile and was associated with the large root biomass in this layer (Table 2) and to a higher $\mathrm{N}$ concentration in the uppermost roots. Mean maximum total $\mathrm{N}$ in the root biomass was around $2 \mathrm{~g} \mathrm{~m}^{-2}$ and occurred in April, coinciding with peak root biomass (Fig. 3 lower panel). Differences in root $\mathrm{N}$ at different depths were significant $(p<0.001)$ (Table 2$)$. Total $\mathrm{N}\left(\mathrm{g} \mathrm{m}^{-2}\right)$ and root $\mathrm{N}$ content (\%) declined with increasing soil depth. Mean total $\mathrm{N}$ in the root biomass within the top $3 \mathrm{~cm}$ soil profile was $1.2 \mathrm{~g} \mathrm{~m}^{-2}$ and basically more than three-quarters of $\mathrm{N}$ in the belowground biomass pool was confined within the top $7 \mathrm{~cm}$ soil layer.

\subsection{Influence of plant functional types on $\mathrm{N}$ allocation}

We examined how the different plant functional types may influence the distribution of $\mathrm{N}$ into the various pools, especially in the aboveground biomass pool, where it was easy to distinguish between functional types. Legumes had significantly $(p<0.05)$ higher $\mathrm{N}$ per unit biomass (around 3\%) in the aboveground biomass compared to forbs and grasses (Fig. 4a). Tissue $\mathrm{N}$ content did not change significantly during the growing season. This also applied to the root $\mathrm{N}$ content. Since it was difficult to separate out roots from the different plant functional types, root data are representative of the entire herbaceous biomass. Because of differences in tissue $\mathrm{N}$ content among the plant functional types, allocation of $\mathrm{N}$ into the aboveground biomass pool was, therefore, influenced by the relative contribution of the respective functional types to the total biomass (Fig. 4b). During 2006, legumes contributed a significant fraction of the total aboveground biomass of the undestroyed compared to the previous two years. This was also the period when we observed the highest $\mathrm{N}$ allocation to the aboveground biomass

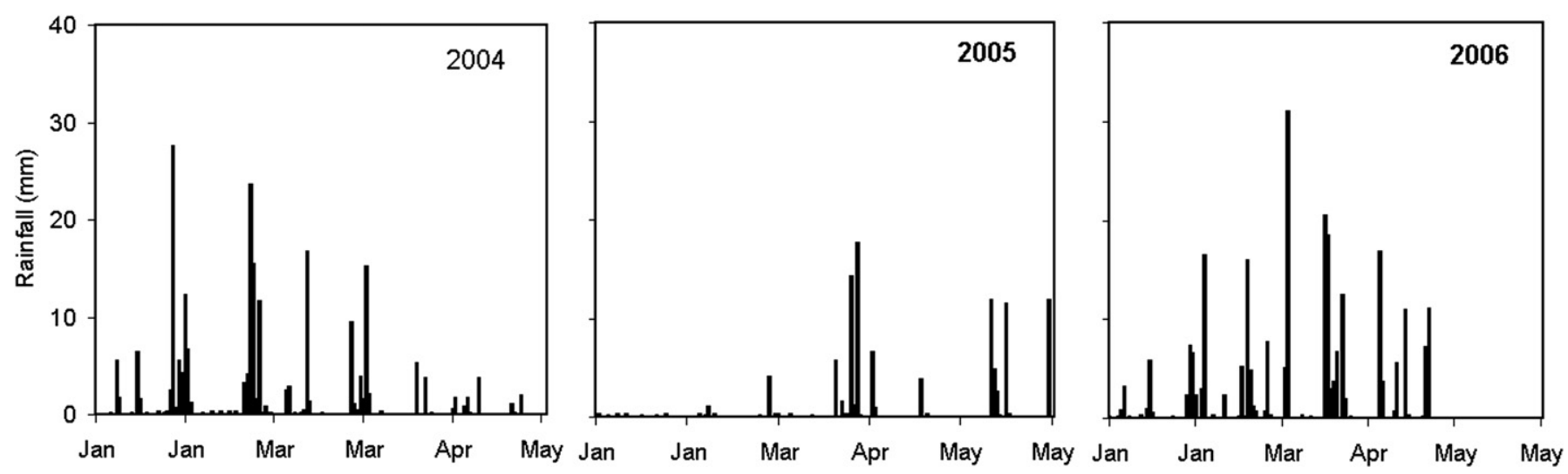

Fig. 1. Daily rainfall amounts during spring period between 2004 and 2006 when measurements were conducted. 

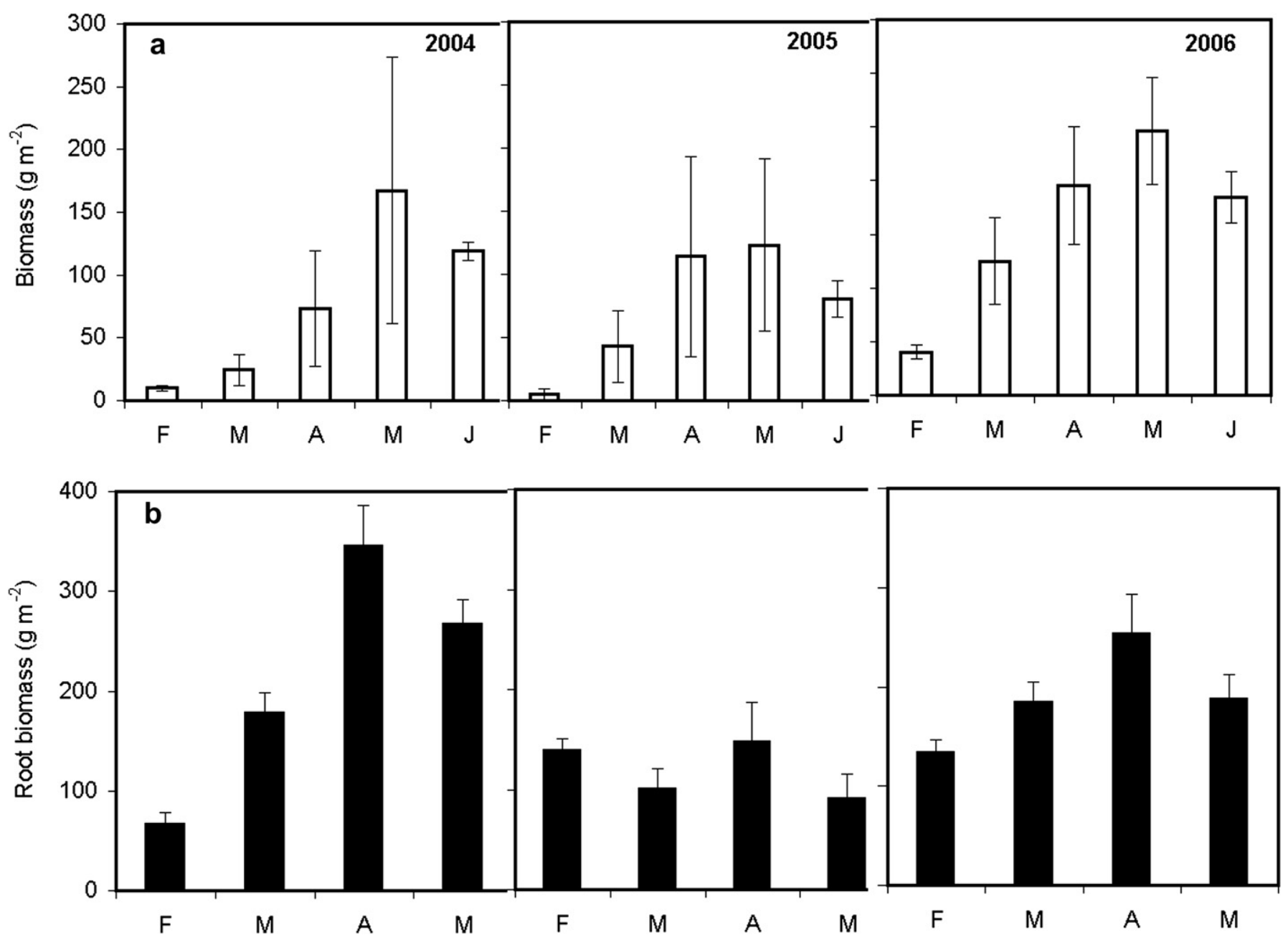

Fig. 2. Aboveground live shoot biomass (a) and root biomass (b) of the herbaceous layer recorded during the spring period between 2004 and 2006 . Bars are \pm 1 SD.

pool. During 2005, grasses were the dominant contributors to the aboveground biomass and the year experienced the lowest $\mathrm{N}$ allocation into the aboveground biomass pool.

\subsection{Soil nitrogen}

Total $\mathrm{N}$ content in the soil pool varied significantly between the months and also with soil depth (Table 3 ) but differences between the years were not significant. Lowest total $\mathrm{N}$ content was between February and March $(0.10 \pm 0.02 \%)$ but soil N increased significantly after March, reaching $0.182 \pm 0.02 \%$ in May. Significantly higher total $\mathrm{N}$ occurred within the top $7 \mathrm{~cm}$ soil layer compared to the deeper layers down to $20 \mathrm{~cm}$ depth. Except in March, the top $3 \mathrm{~cm}$ soil layer had significantly higher $\mathrm{N}$ compared to the 3-7 cm layer, which was richer in $\mathrm{N}$ compared to the lower layers down to $20 \mathrm{~cm}$ depth. Differences between the 7-12 cm and $12-20 \mathrm{~cm}$ soil depths were however not significant. A significant increase in total $\mathrm{N}$ occurred in the deeper soil layers during April and May.

Soil available $\mathrm{N}$ varied significantly between the months, while annual differences were not significant. Maximum total soil $\mathrm{N}$ concentrations were $17.3 \pm 5.9$ and $25.5 \pm 2.5 \mathrm{mg}$ g- 1 soil between March and May of each year. A significant $(p<0.001)$ increase in available $\mathrm{N}-\left(\mathrm{NO}_{3}^{-}\right.$and $\left.\mathrm{NH}_{4}^{+}\right)$in the inorganic $\mathrm{N}$ pool occurred between February and March, coinciding with the period of active plant growth (Fig. 5a). A 3- to 5-fold increase in available $\mathrm{N}$ was observed during this period. Available $\mathrm{N}$ was highest between
March and May and remained relatively constant during this period. There was no significant difference between levels of nitrate $\left(\mathrm{N}-\mathrm{NO}_{3}^{-}\right)$and ammonium $\left(\mathrm{N}-\mathrm{NH}_{4}^{+}\right)$in this pool, and both varied simultaneously. $\mathrm{N}$ in this pool was concentrated within the top 0-3 cm soil profile (Fig. 5b). Except for the months of January/ February, the top $3 \mathrm{~cm}$ soil profile accounted for almost half of the available $\mathrm{N}$ in this pool and $\mathrm{N}$ declined with increasing soil depth, with significant $(p<0.001)$ differences between the layers during most of the months.

\section{Discussion}

The aboveground biomass development of the herbaceous vegetation in the montado is confined to the period between February and May due to low winter temperatures and low soil moisture in summer that hinder plant growth (Otieno et al., 2006). The mean peak aboveground biomass observed in this study was $200 \mathrm{~g} \mathrm{~m}^{-2}$, accumulated within the three months growing period. These values compare favourably with those reported previously for the same ecosystem. Castro and Freitas (2009) reported a similar peak biomass of $200 \mathrm{~g} \mathrm{~m}^{-2}$ for the herbaceous vegetation in a southern Portuguese montado, which shares similar conditions with our study site, while Li et al. (2008) reported peak aboveground biomass of $250 \mathrm{~g} \mathrm{~m}^{-2}$ Moreno (2008) reported peak biomass of $150 \mathrm{~g} \mathrm{~m}^{-2}$ for a similar ecosystem in Spain. The observed rapid growth of the herbaceous biomass during spring was likely due to suitable soil moisture 

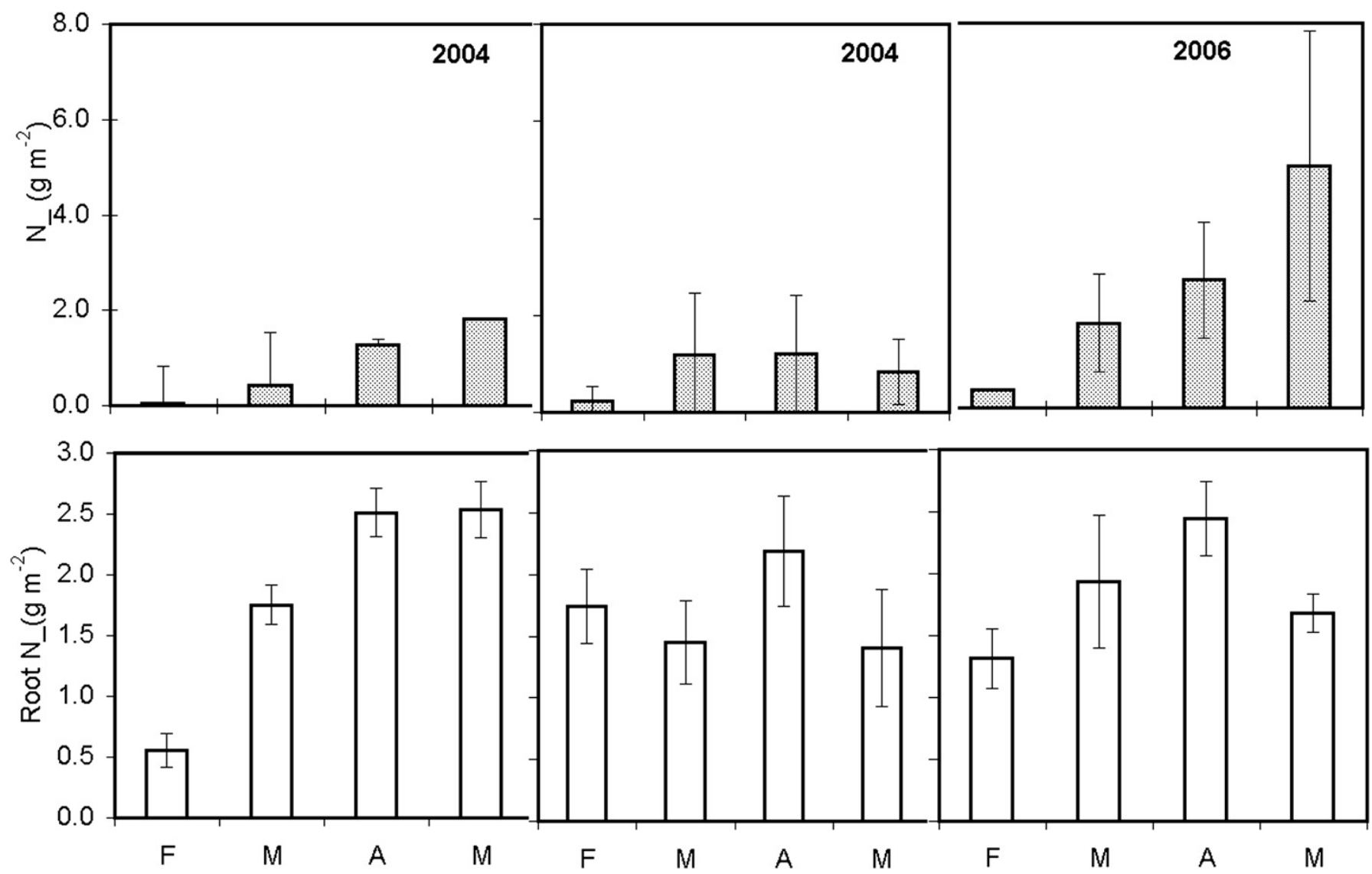

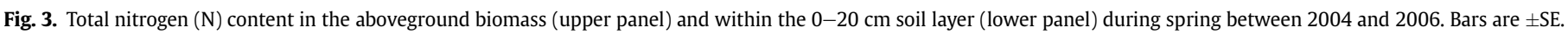

conditions, favourable temperatures and availability of ample soil nutrients.

Plant growth and development are promoted by soil nitrogen availability and N-mineral nutrition (Jackson et al., 1988; Bustamante et al., 2006). Increasing plant biomass, as observed in the herbaceous layer community between February and May in the montado, was associated with increased $\mathrm{N}$ uptake and accumulation in the plant tissues. The average amount of $\mathrm{N}$ relocated into the aboveground biomass pool of the herbaceous vegetation during spring of each year ranged between $2 \mathrm{~g} \mathrm{~m}^{-2}$ and $5 \mathrm{~g} \mathrm{~m}^{-2}$ while the allocation to the roots was approximately $2.4 \pm 1.2 \mathrm{~g} \mathrm{~m}^{-2}$. These values are comparable with $4.21 \pm 1.2 \mathrm{~g} \mathrm{~m}^{-2}$ in the aboveground and $3.2 \pm 1.5 \mathrm{~g} \mathrm{~m}^{-2}$ in the root biomass (down to $30 \mathrm{~cm}$ soil depth) in a Californian Mediterranean ecosystem (Jackson et al., 1988), but lower than $10 \mathrm{~g} \mathrm{~m}^{-2}$ in shoot and $2 \mathrm{~g} \mathrm{~m}^{-2}$ in roots in a North American perennial steppe (Hook et al., 1991). Total peak biomass reported by Hook et al. (1991) was $1200 \pm 50 \mathrm{~g} \mathrm{~m}^{-2}$. This is 6 times the peak biomass reported for our study site. The vegetation was also perennial, indicating that the $10 \mathrm{~g} \mathrm{~m}^{-2} \mathrm{~N}$ was accumulated over a longer time period compared to

Table 2

Root distribution patterns in different soil layers, root $\mathrm{N}$ and $\mathrm{C}$ contents at peak biomass of the herbaceous layer vegetation. Values not sharing the same letter indicate significant differences between soil layers (Tukey-HSD, $p<0.05$ ). Values are means \pm SE.

\begin{tabular}{lclcrc}
\hline Soil depth & $0-3 \mathrm{~cm}$ & $3-7 \mathrm{~cm}$ & $7-12 \mathrm{~cm}$ & \multicolumn{1}{c}{$\mathrm{F}$} & \multicolumn{1}{c}{$p$} \\
\hline Root biomass & $113.1 \pm 13.1^{\mathrm{a}}$ & $31.1 \pm 4.8^{\mathrm{b}}$ & $16.2 \pm 4.1^{\mathrm{b}}$ & 37.9 & $<0.001$ \\
\%N & $1.03 \pm 0.06^{\mathrm{a}}$ & $0.86 \pm 0.04^{\mathrm{b}}$ & $0.8 \pm 0.03^{\mathrm{b}}$ & 7.4 & 0.003 \\
Total root $\mathrm{N}\left(\mathrm{g} \mathrm{m}^{-2}\right)$ & $1.16 \pm 0.21^{\mathrm{a}}$ & $0.28 \pm 0.08^{\mathrm{b}}$ & $0.13 \pm 0.02^{\mathrm{b}}$ & 6.4 & $<0.001$ \\
\% & $31.4 \pm 2.3$ & $30.6 \pm 2.1$ & $30.8 \pm 2.5$ & 0.02 & 0.98 \\
$\mathrm{C}: \mathrm{N}$ & $30.3 \pm 1.3$ & $35.4 \pm 1.4$ & $39.3 \pm 3.7$ & 2.07 & 0.146 \\
\hline
\end{tabular}

the three months at our site. The herbaceous biomass in this Portuguese montado, therefore, had a higher nutrient uptake rate and it is likely that $\mathrm{N}$ is not a limiting factor to biomass development.

Rapid nutrient uptake and accumulation in the herbaceous biomass during spring may deplete $\mathrm{N}$ reserves in the soil. There was however, no decay of soil $\mathrm{N}$ but instead, a 3- to 5-fold increase in total and available $\mathrm{N}$ was observed between February and May, coinciding with the period of rapid plant growth and $\mathrm{N}$ uptake. Soil $\mathrm{N}$ also remained high throughout the period of active herbaceous biomass development (till maturity). Rapid increase of $\mathrm{N}$ in plant biomass during moist and warm months of the year has been reported for similar ecosystems elsewhere (Woodmansee and Duncan, 1980; Jackson et al., 1988) and is attributed to rapid N mineralization during this period (Jackson et al., 1988; Joffre, 1990; Gallardo et al., 2000). Although we did not examine mineralization rates in these soils, Joffre (1990) and Gallardo et al. (2000) observed a 2- to 4-fold increase in mineralization rates between February and April in the Spanish dehesa, which shares similar ecosystems and soil types with the Portuguese montado. Increased mineralization rates in Mediterranean-type ecosystems during spring have also been reported by Jackson et al. (1988). The synchronised increase in soil $\mathrm{N}$ content with plant growth ensures adequate $\mathrm{N}$ availability and its optimal utilisation. The fact that both total soil $\mathrm{N}$ and available $\mathrm{N}$ remained high in May, when the herbaceous layer had reached maturity and senescence strongly indicate that the herbaceous layer development might not create $\mathrm{N}$ deficit in the montado.

The herbaceous layer community is dominated by shallow rooted annuals and relies heavily on surface soil N (Jackson et al., 1988; Moreno et al., 2005b; Jobbágy and Jackson, 2001). Most of the herbaceous root biomass was located within the top $7 \mathrm{~cm}$ soil 

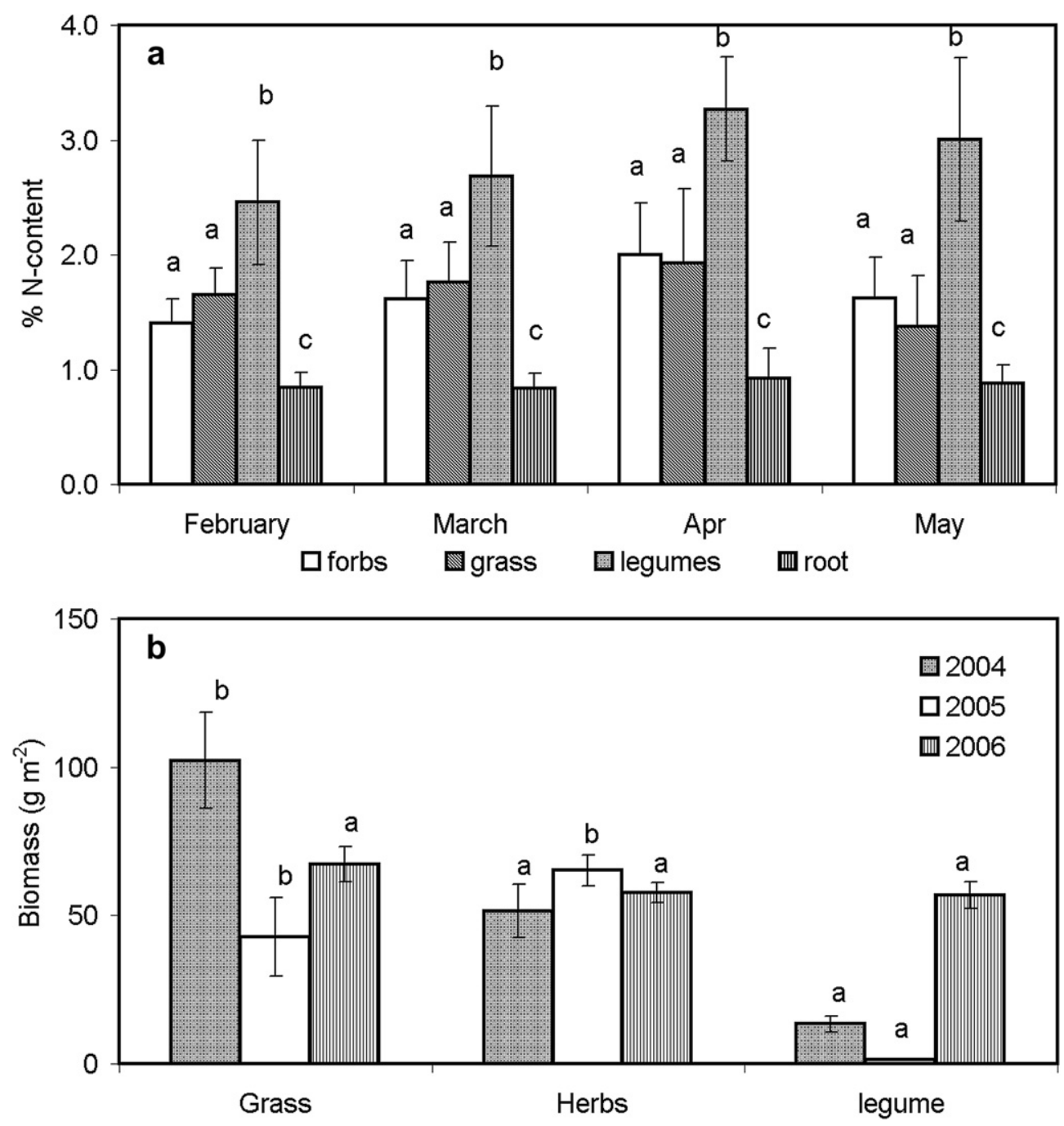

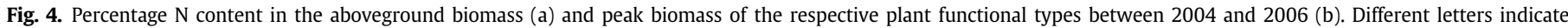
significant differences in biomass between years (Tukey-HSD, $p<0.05$ ). Bars are \pm SE.

profile and this was also true for both available and total soil N. This distribution pattern promotes rapid and efficient nutrient $\mathrm{N}$ uptake (Moreno et al., 2005b; Schenk and Jackson, 2002). On the other hand, the observed patterns of root and $\mathrm{N}$ distribution, as well as the relationship between biomass development and changes in available $\mathrm{N}$ concentrations suggest that the herbaceous layer may contribute to $\mathrm{N}$ mineralization process (Jackson et al., 1990). Production of $\mathrm{NH}_{4}^{+}$, which is the main source of nitrification, is regulated by the amount of labile organic carbon (Whitehead, 1995). We observed a significant increase in $\mathrm{NH}_{4}^{+}$and $\mathrm{NH}_{3}^{-}$during

Table 3

Total nitrogen content in different soil layers in spring. ${ }^{*} p<0.05,{ }^{* *} p<0.001$, indicate significant differences between months. Values not sharing the same letters indicate significant differences between soil layers (Tukey-HSD, $p<0.05$ ). Values are means \pm SE.

\begin{tabular}{lllll}
\hline \multirow{2}{*}{ Depth $(\mathrm{cm})$} & \multicolumn{4}{l}{ Total N content $(\%)$} \\
\cline { 2 - 5 } & Feb & March & April & \multicolumn{1}{l}{ May } \\
\hline $0-3$ & $0.120 \pm 0.02^{\mathrm{a}}$ & $0.092 \pm 0.01^{\mathrm{a}}$ & $0.172 \pm 0.01^{\mathrm{a} * *}$ & $0.182 \pm 0.02^{\mathrm{a} * *}$ \\
$3-7$ & $0.070 \pm 0.06^{\mathrm{b}}$ & $0.085 \pm 0.01^{\mathrm{a}}$ & $0.097 \pm 0.01^{\mathrm{b} *}$ & $0.10 \pm 0.01^{\mathrm{b} *}$ \\
$7-12$ & $0.055 \pm 0.003^{\mathrm{b}}$ & $0.05 \pm 0.005^{\mathrm{b}}$ & $0.064 \pm 0.005^{\mathrm{c}}$ & $0.063 \pm 0.005^{\mathrm{c}}$ \\
$12-20$ & $0.044 \pm 0.002^{\mathrm{b}}$ & $0.034 \pm 0.002^{\mathrm{b}}$ & $0.074 \pm 0.05^{\mathrm{c}}$ & $0.065 \pm 0.004^{\mathrm{c}}$ \\
\hline
\end{tabular}
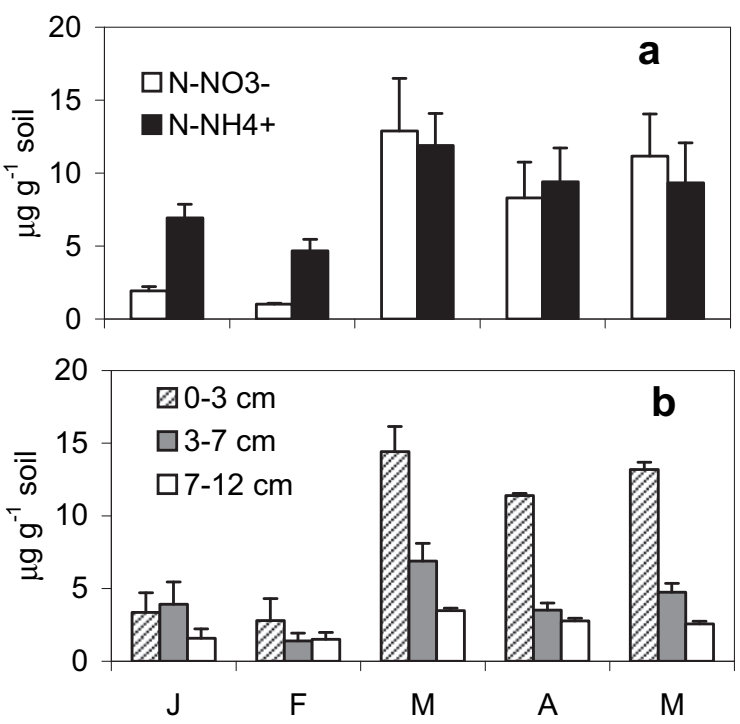

Fig. 5. Temporal (a) and spatial (vertical) (b) distribution of mineral nitrogen ( $\mathrm{N}-\mathrm{NO}_{3}^{-}$ and $\mathrm{N}-\mathrm{NH}_{4}^{+}$) within the top $12 \mathrm{~cm}$ soil profile during spring. Bars are $\pm \mathrm{SE}$. 
spring, associated with increasing biomass of the herbaceous layer. This led to an increase in total soil $\mathrm{N}$ input as observed between March and May. Major input of soil organic matter in the open locations of the montado ecosystem comes from the herbaceous vegetation, which actively photosynthesises during spring (Pereira et al., 2007; Aires et al., 2008; Li et al., 2008). Development of the herbaceous biomass in spring, therefore, is likely to increase $\mathrm{N}$ mineralization through increased inputs of labile organic compounds and total organic and respirable carbon (Hook et al., 1991). Similar conclusions were drawn by Gallardo et al. (2000). The presence of legumes in the herbaceous layer community, which have the capacity to fix atmospheric N (Hamdi, 1999) may also improve levels of available $\mathrm{N}$ in the soil, as suggested by the higher tissue $\mathrm{N}$ in legumes, which is probably as a result of high $\mathrm{N}$ availability at their rhizosphere. The observed increase in total $\mathrm{N}$ in the deeper soil layers between April and May suggests a recharge of deeper soil layers with $\mathrm{N}$ that likely originates from the shallow soil layers.

Most annuals in the montado cannot withstand drought (Fernandez-Ales et al., 1993; Pereira et al., 2007; Aires et al., 2008). They complete seed production during the short period of high soil water availability and are withered by June, leaving a significant fraction of inorganic $\mathrm{N}$ in the soil. This may become available to other plant life forms that have an extended life span (Jackson et al., 1990), or is lost through leaching during the fall and winter rains, as demonstrated by the lower total and inorganic $\mathrm{N}$ in February of the following year. The period between June and January were not covered by our study, hence we were unable to follow changes in soil $\mathrm{N}$ during these times. Studies carried out in a similar ecosystem (Joffre, 1990) observed a significant decline in $\mathrm{NO}_{3}^{-}$and $\mathrm{NH}_{4}^{+}$during fall and winter and attributed it to lack of mineralization due to low temperatures and losses through leaching. Whitehead (1995) observed that most of the available $\mathrm{N}$ during winter is either leached or denitrified. It is likely that lower total and mineral $\mathrm{N}$ observed in February compared to May, was likely due to nutrient loss through leaching, most of which likely disappears from the ecosystem. At peak biomass of the herbaceous layer, a significant amount of $\mathrm{N}$ is locked up in the plant tissue. In the absence of grazing, most of this organic $\mathrm{N}$ is returned into the soil with the biomass. Retaining $\mathrm{N}$ in organic form is, therefore, advantageous since it is not easily lost through leaching during the rainy period (Haynes, 1986; Gallardo and Merino, 1992) when the herbaceous layer is absent and low temperatures do not allow active plant growth.

\section{Conclusions}

We observed a significant relocation of $\mathrm{N}$ into the plant biomass pool during rapid biomass development of the herbaceous layer in spring. During this period however, there was significant increase in mineral $\mathrm{N}$ in the inorganic $\mathrm{N}$ pool, as well as total $\mathrm{N}$ in the soil and no decay in soil $\mathrm{N}$ occurred despite rapid herbaceous layer proliferation. This strongly suggests that the herbaceous layer does not deplete soil $\mathrm{N}$ during its growth period in spring. The distribution trend of available $\mathrm{N}$ and herbaceous roots in the soil profile and the patterns of plant growth and $\mathrm{N}$ quantities in the soil demonstrate this. Possible mechanisms by which the herbaceous layer may realize this include direct $\mathrm{N}$ fixation by legumes or provision of labile soil carbon that activate the microbial community. We also observed a significant increase of $\mathrm{N}$ in the deeper soil layers during April and May, a demonstration of deeper soil layer recharge. This $\mathrm{N}$ may then become available to the deep-rooted vegetation like trees according to the spatial separation of the herbaceous vegetation and tree rooting systems in the montado. Retention of $\mathrm{N}$ in organic form in the detritus arising from the herbaceous biomass also serves to retain $\mathrm{N}$ within the ecosystem. We conclude that the herbaceous layer is a vital component of the montado ecosystem, enabling effective $\mathrm{N}$ recycling and retention within the ecosystem.

\section{Appendix. Supplementary data}

Supplementary data associated with this article can be found in the on-line version, at doi:10.1016/j.jaridenv.2010.10.011.

\section{References}

Aires, L.M., Pio, C.A., Pereira, J.S., 2008. Carbon dioxide exchange above Mediterranean C3/C4 grassland during two climatologically contrasting years. Global Change Biology 14, 539-555.

Bugalho, M., Plieninger, T., Aronson, J., Ellatifi, M., Crespo, D., 2009. Open woodlands: a diversity of uses (and overuses). In: Aronson, J., Pereira, J.S., Pausas, J.G. (Eds.), Cork Oak Woodlands in Transition: Ecology, Adaptive Management, and Restoration of an Ancient Mediterranean Ecosystem. Island Press, New York, pp. 33-48.

Bustamante, M.M.C., Medina, E., Ansner, G.P., Nardoto, G.B., Garcia-Montiel, D.C. 2006. Nitrogen cycling in tropical and temperate savannas. Biogeochemistry 79, 209-237.

Castro, H., Freitas, H., 2009. Above-ground biomass and productivity in the montado: from herbaceous to shrub dominated communities. Journal of Arid Environments 73, 506-511.

Corte-Real, J., Budong, Q., Hong, X., 1998. Regional climate change in Portugal: precipitation variability associated with large-scale atmospheric circulation. International Journal of Climatology. 18, 612-635.

Diaz, M., Campos, P., Pulido, F.J., 1997. The Spanish dehesas: a diversity in land use and wildlife. In: Pain, D.J., Pienkowsky, M.W. (Eds.), Conservation Farming and Birds in Europe. The Common Agricultural Policy and Its Implementations for Bird. Academic Press, London, pp. 178-209.

FAO, 1988. FAO/UNESCO Soil Map of the World, Revised Legend, with Corrections. World Resources Report 60. FAO, Rome. Reprinted as Technical Paper 20. ISRIC, Wageningen. 1994.

Fernandez-Ales, R., Ortega, F., Laffarga, J., 1993. Strategies in Mediterranean grassland annuals in relation with stress and disturbance. Journal of Vegetation Science 4, 313-322.

Gallardo, A., 2003. Effect of tree canopy on the spatial distribution of soil nutrients in a Mediterranean dehesa. Pedobiologia 47, 117-125.

Gallardo, A., Merino, J., 1992. Nitrogen immobilisation in leaf litter at two Mediterranean ecosystems of SW Spain. Biogeochemistry 15, 213-228.

Gallardo, A., Rodriguez-Saucedo, J.J., Covelo, F., Fernandez-Ales, R., 2000. Soil nitrogen heterogeneity in a dehesa ecosystem. Plant and Soil 222, 71-82.

Garwood, E.A., Tyson, K.C., 1973. Loses of nitrogen and other plant nutrients to drainage from soil under grass. Journal of Agricultural Science 80, 308-312.

Hamdi, H.Z., 1999. Rhizobium-legume symbiosis and nitrogen fixation under severe conditions and in an arid climate. Microbiology and Molecular Biology Reviews 63, 968-989.

Haynes, R.J., 1986. The decomposition process: mineralization immobilization, humus formation and degradation. In: Haynes, R.J. (Ed.), Mineral Nitrogen in the Plant-Soil System. Academic Press, London, pp. 52-126.

Hook, P.B., Burke, I.C., Lauenroth, W.K., 1991. Heterogeneity of soil and plant N and C associated with individual plants and openings in North American shortgrass steppe. Plant and Soil 138, 247-256.

Infante, J.M., Damesin, C., Rambal, S., Fernández-Alésa, R., 1999. Modelling leaf gas exchange in holm-oak trees in southern Spain. Agriculture Forest and Meteorology 95, 203-223.

Jackson, L.E., Strauss, R.B., Firestone, M.K., Bartolome, J.W., 1988. Plant and soil nitrogen dynamics in California annual grassland. Plant and Soil 110, 9-17.

Jackson, L.E., Strauss, R.B., Firestone, M.K., Bartolome, J.W., 1990. Influence of tree canopy on grassland productivity and nitrogen dynamics in a deciduous oak savanna. Agriculture Ecosystems and Environment 32, 89-105.

Jobbágy, E.G., Jackson, R.B., 2001. The distribution of soil nutrients with depth: global patterns and the imprint of plants. Biogeochemistry 53, 51-77.

Joffre, R., 1990. Plant and soil nitrogen dynamics in Mediterranean grasslands: a comparison of annual and perennial grasses. Oecologia 85, 142-149.

Joffre, R., Lacaze, B., 1993. Estimating tree density in oak savanna-like 'dehesa' of southern Spain from SPOT data. International Journal of Remote Sensing 14, 685-697.

Joffre, R., Rambal, S., 1988. Soil water improvement by trees in the rangelands of Southern Spain. Acta Oecologica Oecologia Plantarum 9, 405-422.

Joffre, R., Vacher, J., De Los Llanos, C., Long, G., 1988. The Dehasa: an agrosilvopastoral system of the Mediterranean region with special reference to the Sierra Morena area of Spain. Agroforestry Systems 6, 71-96.

Joffre, R., Rambal, S., Ratte, J.P., 1999. The dehesa system of southern Spain and Portugal as a natural ecosystem mimic. Agroforestry Systems 45, 57-79.

Li, Y., Tenhunen, J., Mirzaei, H., Hussain, M.Z., Siebicke, L., Foken, T., Otieno, D., Schmidt, M., Ribeiro, N., Aires, L., Pio, C., Banza, J., Pereira, J., 2008. Assessment and up-scaling of $\mathrm{CO}_{2}$ exchange by patches of the herbaceous vegetation mosaic in a Portuguese cork oak woodland. Agricultural and Forest Meteorology 148, $1318-1331$. 
Markert, B., 1996. Instrumental Element and Multi-Element Analysis of Plant Samples - Methods and Applications. John Wiley and Sons, New York.

Moreno, G., 2008. Response of understorey forage to multiple tree effects in Iberian dehesas. Agriculture Ecosystem and Environment 123, 239-244.

Moreno, G., Cubera, E., 2008. Impact of stand density on water status and leaf gas exchange in a Quecus ilex. Forest Ecology and Management 254, 74-84.

Moreno, G., Obrador, J., García, E., Cubera, E., Montero, M.J., Pulido, F., 2005a. Consequences of dehesa management on the tree-understory interactions. In: Mosquera-Losada, M.R., Riguero-Rodriguez, A., McAdam, J. (Eds.), Silvopastoralism and Sustainable Land Management. CAB International, Oxon, pp. 263-265.

Moreno, G., Obrador, J.J., Cubera, E., Dupraz, C., 2005b. Fine root distribution in dehesas of central-western Spain. Plant and Soil 277, 153-162.

Moreno, G., Obrador, J.J., García, E., Cubera, E., Montero, M.J., Pulido, F., Dupraz, C., 2007. Driving competitive and facilitative interactions in oak dehesas through management practices. Agroforestry Systems 70, 25-40.
Otieno, D.O., Kurz-Besson, C., Liu, J., Schmidt, M.W.T., Vale-Lobo, do, R., David, T.S. Siegwolf, R., Pereira, J.S., Tenhunen, J.D., 2006. Seasonal variation in soil and plant water status in a Quecus suber L stand: roots as determinants of tree productivity and survival in the Mediterranean-type ecosystem. Plant and Soil $283,119-135$.

Pereira, J.S., Mateus, J.A., Aires, L.M., Pita, G., Pio, C., Andrade, V., Banza, J., David, T.S Rodrigues, A., David, J.S., 2007. Effects of drought - altered seasonality and low rainfall - in net ecosystem carbon exchange of three contrasting Mediterranean ecosystems. Biogeosciences 4, 1703-1736.

Schenk, H.J., Jackson, R.B., 2002. Rooting depths, lateral root spreads and belowground/above-ground allometries of plants in water-limited ecosystems. Journal of Ecology 90, 480-494.

Whitehead, D.C., 1995. Grassland Nitrogen. CAB International, Willingford, UK 397pp.

Woodmansee, R.G., Duncan, D.A., 1980. Nitrogen and phosphorus dynamics and budgets in annual grasslands. Ecology 61, 893-904. 